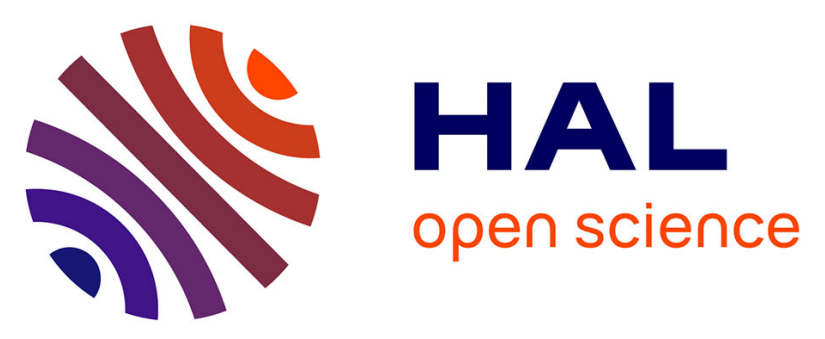

\title{
Medium-throughput ESR detection of superoxide production in undetached adherent cells using cyclic nitrone spin traps
}

K. Abbas, M. Hardy, F. Poulhès, H. Karoui, P. Tordo, O. Ouari, F. Peyrot

\section{- To cite this version:}

K. Abbas, M. Hardy, F. Poulhès, H. Karoui, P. Tordo, et al.. Medium-throughput ESR detection of superoxide production in undetached adherent cells using cyclic nitrone spin traps. Free Radical Research, 2015, 49 (9), pp.1122 - 1128. 10.3109/10715762.2015.1045504 . hal-01414556

\author{
HAL Id: hal-01414556 \\ https://hal.science/hal-01414556
}

Submitted on 22 May 2020

HAL is a multi-disciplinary open access archive for the deposit and dissemination of scientific research documents, whether they are published or not. The documents may come from teaching and research institutions in France or abroad, or from public or private research centers.
L'archive ouverte pluridisciplinaire HAL, est destinée au dépôt et à la diffusion de documents scientifiques de niveau recherche, publiés ou non, émanant des établissements d'enseignement et de recherche français ou étrangers, des laboratoires publics ou privés. 
This is an Accepted Manuscript of an article published by Taylor \& Francis in Free Radical Research on 5 June 2015, available online: http://www.tandfonline.com/0.3109/10715762.2015.1045504

Medium-throughput ESR detection of superoxide production in undetached adherent cells using cyclic nitrone spin traps

Kahina Abbas $^{\mathrm{a}}$, Micael Hardy ${ }^{\mathrm{b}}$, Florent Poulhès ${ }^{\mathrm{b}}$, Hakim Karoui ${ }^{\mathrm{b}}$, Paul Tordo ${ }^{\mathrm{b}}$, Olivier Ouari $^{\mathrm{b}}$, and Fabienne Peyrot ${ }^{\mathrm{a}, \mathrm{c}^{*}}$

${ }^{\text {a }}$ LCBPT, UMR 8601 CNRS - Paris Descartes University, Sorbonne Paris Cité, Paris, France.

${ }^{\mathrm{b}}$ Aix-Marseille University, CNRS, ICR UMR 7273, Marseille, France.

${ }^{c}$ ESPE of Paris, Paris Sorbonne University, Paris, France.

* Corresponding author: Fabienne Peyrot

45 rue des Saints-Pères

75006 Paris, France

Tel : $33(0) 142862175$

E-mail : fabienne.peyrot@ parisdescartes.fr

Running title: Superoxide detection in adherent cells

Keywords: EPR spectroscopy, Spin trapping, RAW macrophages, Free radical, CDDIPPMPO.

\begin{abstract}
Spin trapping with cyclic nitrones coupled to electron spin resonance (ESR) is recognized as a specific method of detection of oxygen free radicals in biological systems, especially in culture cells. In this case, the detection is usually performed on cell suspensions, which is however unsuitable when adhesion influences free radical production. Here, we performed ESR detection of superoxide with four spin traps (5-diethoxyphosphoryl-5-methyl-1pyrroline $\mathrm{N}$-oxide, DEPMPO; 5-diisopropoxyphosphoryl-5-methyl-1-pyrroline $\mathrm{N}$-oxide, DIPPMPO; $\quad\left(4 R^{*}, \quad 5 R^{*}\right)-5$-(diisopropyloxyphosphoryl)-5-methyl-4-[( $\{[2-$ (triphenylphosphonio)ethyl]carbamoyl \}oxy)methyl]pyrroline $N$-oxide bromide, MitoDIPPMPO; and 6-monodeoxy-6-mono-4-[(5-diisopropoxyphosphoryl-5-methyl-1-pyrroline$\mathrm{N}$-oxide)-ethylenecarbamoyl-(2,3-di- $O$-methyl) hexakis (2,3,6-tri- $O$-methyl)]- $\beta$-cyclodextrin, CD-DIPPMPO) directly on RAW 264.7 macrophages cultured on microscope coverslip glasses after phorbol 12-myristate 13-acetate (PMA) stimulation. Distinct ESR spectra were obtained with each spin trap using this method. CD-DIPPMPO, a recently published phosphorylated cyclic nitrone bearing a permethylated $\beta$-cyclodextrin moiety, was confirmed as the most specific spin trap of superoxide radical with exclusive detection of the superoxide adduct. ESR detection performed on cells attached to coverslips represents significant advances over other methods in terms of simplicity, speed, and measurement under nearphysiological conditions. It thus opens the way for numerous applications, such as mediumthroughput screening of antioxidants and reactive oxygen species (ROS)-modulating agents.
\end{abstract}


This is an Accepted Manuscript of an article published by Taylor \& Francis in Free Radical Research on 5 June 2015, available online: http://www.tandfonline.com/0.3109/10715762.2015.1045504

\section{Introduction}

ROS are important by-products of aerobic metabolism, involved in various diseases, but they also play a major part in cell signaling[1]. Spin trapping with cyclic nitrones combined to ESR is the gold standard for the detection of oxygen radical species, such as superoxide $\left(\mathrm{O}_{2}{ }^{-}\right)$ or hydroxyl radical (HO), in cellular systems[2-13]. However interpretation of spin trapping results in cells may be difficult and lots of controls are required. DMPO (5,5-dimethyl-1pyrroline $\mathrm{N}$-oxide), the historical spin trap, reacts with hydroxyl radical to form the adduct DMPO-OH. Detection of DMPO-OH following incubation with stimulated neutrophils was initially considered a proof of hydroxyl radical production by these cells[3,4]. However DMPO-OOH, the adduct obtained by reaction with $\mathrm{O}_{2}{ }^{--}$, spontaneously decomposes into several species, including DMPO-OH[14,15]. In addition DMPO-OOH can be rapidly reduced to DMPO-OH by glutathione-peroxidase[6], an enzyme present in cells, such as endothelial cells, neutrophils, or macrophages[16]. Thus detection of DMPO-OH does not unequivocally prove the formation of hydroxyl radical (Figure 1) and stimulated neutrophils have then been shown not to produce hydroxyl radical[8]. Amelioration of the technique has occurred over the years with spin traps that form superoxide adducts with longer life time in buffer and that do not spontaneously decompose to superoxide adducts[17]. Today, DEPMPO[18-21] is frequently used as a spin trap but novel spin traps, derived from the diisopropyloxyphosphoryl analogue DIPPMPO[22] and bearing a triphenylphosphonium (Mito-DIPPMPO) or a permethylated $\beta$-cyclodextrin moiety (CD-DIPPMPO), were recently demonstrated to form adducts of increased stability in buffer (Figure 1)[23]. CD-DIPPMPO is especially sensitive and specific of extracellular superoxide, as demonstrated with living macrophage suspensions studied in gas-permeable Teflon tubing[24]. These properties were attributed to the $\beta$-cyclodextrin moiety that prevents the spin trap to enter cells and ensures hydroxyl radical does not react with the nitrone function[23,24]. The penetration of cells by spin traps is an important parameter to understand spin trapping results. DMPO and DEPMPO, and their hydroxyl adducts, have been shown to rapidly penetrate lipid bilayers[25]. DIPPMPO, being more lipophilic, is supposed to be more suitable for trapping in subcellular compartments[22] and Mito-DIPPMPO, being conjugated to a large lipophilic triphenylphophonium cation, is assumed to be accumulated 5-10 fold in the cytoplasm, driven by the plasma membrane potential, and further accumulated in the mitochondria [26]. Inside cells, superoxide adducts of all these spin traps are subject to conversion to the corresponding hydroxyl adducts by action of thiols with or without catalysis by glutathione-peroxidase as shown with purified enzymatic systems or subcellular fractions [23,24,27,28].

Results obtained with suspensions of adherent cells may occasionally differ from physiological responses. To overcome this issue, a number of solutions have been proposed, such as allowing cells to adhere to quartz flat ESR cuvettes[29], using a custom made flowtype quartz cuvette[30] or ESR cavity[31], or using microcarrier bead cultures[32,33]. Oxygen supply can however be an issue with some of these setups. Since experimentation on biological material requires the comparison of numerous conditions and repetition of experiments for statistical analysis, it is desired to find easily accessible and convenient systems to analyze large numbers of samples in a single day under near-physiological conditions. In this study, we show that ESR detection can be performed directly on coverslip glasses initially designed for microscope studies. 
This is an Accepted Manuscript of an article published by Taylor \& Francis in Free Radical Research on 5 June 2015, available online: http://www.tandfonline.com/0.3109/10715762.2015.1045504

\section{Methods}

Reagents

DIPPMPO was synthesized according to previously published protocols[22]. Purity was determined by NMR and HPLC coupled with mass spectrometry and was above $98 \%$. MitoDIPPMPO and CD-DIPPMPO were prepared using the procedures described for diethoxyphosphoryl analogues[28,34,35]. Their NMR and electrospray ionization-highresolution mass spectrometry (ESI-HRMS) characterizations were previously published[23]. DEPMPO was obtained from Radical Vision (Marseille, France). Diethylene triamine pentaacetic acid (DTPA), xanthine (X), xanthine oxidase (XO), superoxide dismutase conjugated with polyethylene glycol (SOD-PEG), phosphate-buffered saline (PBS, pH 7.17.5) were purchased from Sigma-Aldrich (Saint Quentin Fallavier, France).

\section{Culture of RAW macrophages}

Macrophages (RAW 264.7 cells), originally purchased from American Type Culture Collection (ATCC, CRL-9609TM), were a kind gift from Dr Jean-Claude Drapier (CNRS UPR 2301, Gif-sur-Yvette, France). Cells were cultured in Dulbecco's Modified Eagle Medium (DMEM AQmedia, Sigma-Aldrich) supplemented with 5\% fetal bovine serum (Lonza, Levallois-Perret, France) and $1 \%$ penicillin/streptomycin (Invitrogen) in a water-jacketed incubator under $5 \% \mathrm{CO}_{2}$ at $37^{\circ} \mathrm{C}$.

\section{Spin trapping of superoxide radical produced by macrophages}

On the day prior to experiment, RAW cells were placed on round microscope coverslip glasses (diameter $12 \mathrm{~mm}$, thickness 0.13-0.16 mm, Thermo Scientific Menzel, Braunschweig, Germany) inserted in a 24-well culture plate and covered with $500 \mu \mathrm{L}$ DMEM. When indicated, confluent cells on two coverslips (250 000 cells/coverslip) were stimulated with PMA $\left(5 \mu \mathrm{M}, 20 \mathrm{~min}, 37^{\circ} \mathrm{C}\right)$, then washed twice with $500 \mu \mathrm{L}$ of PBS, and incubated for 20 min at $21^{\circ} \mathrm{C}$ with the desired spin trap $(5-10 \mathrm{mM})$, DTPA $(1 \mathrm{mM})$, and PBS (final volume 150 $\mu \mathrm{L}$ ). The back of the coverslips were slightly dabbed with paper tissue, secured (cell-layer facing outwards) on a quartz slide $(130 \times 12 \times 1.5 \mathrm{~mm})$ with a minimum of ESR-silent silicon vacuum grease (Bluestar silicones, Caronno Pertusella, Italy), and introduced in the ESR cavity equipped with a flat quartz protection sleeve (Figure 2). A 24-well culture plate represents thus the opportunity of screening 12 conditions on the same batch of culture cells within half a day.

For comparison purposes, cell suspensions of RAW macrophages $\left(3.6 \pm 0.3 \times 10^{6}\right.$ cells $\left./ 100 \mu \mathrm{L}\right)$ prepared as described in a previous work[24] were inserted in gas-permeable PTFE tubing (Extruded Sub-Lite-Wall ${ }^{\circledR}$, inside diameter: $0.635 \mathrm{~mm}$, wall thickness: $0.051 \mathrm{~mm}$, Zeus Industrial Products Ltd., Ireland) or glass microcapillary pipettes (50 $\mu \mathrm{L}$, Hirschmann).

\section{ESR spectroscopy}

ESR measurements were performed using an Elexsys 500 ESR spectrometer (Bruker, Wissembourg, France), operating at X-band $(9.8 \mathrm{GHz})$ and equipped with a TM cavity. Typical settings used were: microwave power, $10 \mathrm{~mW}$; modulation frequency, $100 \mathrm{kHz}$; modulation amplitude, $0.2 \mathrm{mT}$; receiver gain, $60 \mathrm{~dB}$; time constant, $40.96 \mathrm{~ms}$; conversion time, $41.04 \mathrm{~ms}$; datapoints, 1024; sweep width, $15 \mathrm{mT}$; sweep time, $42.02 \mathrm{~s}$. ESR spectra 
This is an Accepted Manuscript of an article published by Taylor \& Francis in Free Radical Research on 5 June 2015, available online: http://www.tandfonline.com/0.3109/10715762.2015.1045504

were recorded sequentially at $21^{\circ} \mathrm{C}$. Data acquisition and processing were performed using Bruker Xepr software. Baseline correction of ESR spectra was performed by subtracting the signal obtained when the spin trap was omitted.

\section{Computer simulations}

Computer simulations of the ESR spectra were performed using the program of Rockenbauer and Korecz[36]. In addition to the g-factor and hyperfine coupling constants, the relaxation and exchange parameters were optimized from the best resolved spectra, and when necessary, two or three superimposed components were taken into account as described in previous works[23,24]. These parameters are listed in Table 1. Normalized line shapes were used, giving concentration data for all components in arbitrary units.

\section{Results}

\section{Detection of superoxide on adherent cells with DEPMPO}

Superoxide radical production by RAW macrophages attached to microscope coverslip glasses was induced by 20 min incubation with $5 \mu \mathrm{M}$ PMA at $37^{\circ} \mathrm{C}$. Subsequent trapping of the radical with $10 \mathrm{mM}$ DEPMPO enabled the detection of a significant ESR signal, characteristic of a mixture of superoxide and hydroxyl radical spin adducts in a 1:9 ratio (Figure 3, upper-left panel). Addition of $200 \mathrm{U}$ of SOD-PEG, a membrane-permeative superoxide dismutase but that is incorporated very slowly within the cells[37], strongly inhibited the detection of both superoxide and hydroxyl radical adducts, whereas no signal was observed in the absence of PMA (Supplementary Figure S1).

Optimization of the conditions of ESR recordings was performed. It was observed that best results were obtained after 20 min incubation with the spin trap, post PMA-stimulation. Earlier recording start times did not allow optimal accumulation of the spin adducts. Besides, spin adduct decay could not be ignored when measurement start was delayed by more than 20 min. Use of two coverslip glasses as indicated in Figure 2 increased the signal compared to the use of a single coverslip because the microwave excitation spreads over a sample height of $\sim 2 \mathrm{~cm}$ in the resonator. In our first attempts, the cell-layer on the coverslips was arranged facing the quartz slide but we observed 50\% more signal when the cell-layer faced outwards, with the coverslips mounted onto the quartz slide using vacuum grease, probably due to better diffusion of oxygen to the cell layer. The ESR measurement was then restricted to 10 min to prevent the cell-layer from drying out; the signal remained stable during this period.

\section{Comparison of the spin traps}

Representative ESR spectra obtained for four cyclic nitrone spin traps with PMA-stimulated RAW macrophages attached to two coverslip glasses are shown in Figure 3. A concentration of $10 \mathrm{mM}$ was used for each spin trap except for CD-DIPPMPO $(5 \mathrm{mM})$, because aggregation tends to reduce the spin trapping rate of the latter at higher concentrations. In most cases, the PMA-dependent signal resulted from overlapping components and computer simulation was required to extract the respective contributions of superoxide and hydroxyl radical adducts displayed in Figure 4. DIPPMPO behaved in a similar way to DEPMPO but with half the sensitivity; DIPPMPO-OH was responsible for $90 \%$ of the signal. On the 
This is an Accepted Manuscript of an article published by Taylor \& Francis in Free Radical Research on 5 June 2015, available online: http://www.tandfonline.com/0.3109/10715762.2015.1045504

contrary, the superoxide adduct was the major component with Mito-DIPPMPO (80\%). CDDIPPMPO was the most specific spin trap because the CD-DIPPMPO-OH adduct was below detection limit in our study. Moreover the level of CD-DIPPMPO-OOH equaled the sum of DEPMPO-OOH and DEPMPO-OH adducts.

\section{Discussion}

The production of superoxide by PMA-stimulated RAW macrophages was measured by ESR spectroscopy without detachment of the cells from microscope coverslip glasses. PMA is a specific activator of protein kinase $\mathrm{C}$, which in turn performs the phosphorylation of a critical residue in NADPH oxidase (NOX2) in the macrophage membrane[38]. According to the principles of spin trapping, superoxide radical reacts with the ESR-silent cyclic nitrone, e. g. DEPMPO, to form a persistent radical, referred to as the superoxide adduct (Figure 1), characterized by a distinctive ESR spectrum. The stability of this adduct within cells can be decreased by various pathways (involving reductases, ascorbate, thiols, or heme proteins) as shown in previous works[6,23,39-41]. Especially, DEPMPO-OOH is converted to DEPMPO-OH by thiols and glutathione-peroxidase[27], an enzyme present in RAW macrophages[16]. In the present study, a high proportion of hydroxyl radical adduct was observed in the experiment with DEPMPO (Figure 3 and Figure 4), but its level was reduced upon incubation with SOD-PEG (Supplementary Figure S1). Under our conditions with rather short incubation times, most of SOD-PEG remains in the extracellular space where it reacts with superoxide at diffusion-controlled rates[37] and efficiently competes with the spin trap (which reacts with superoxide at rates that do not approach $100 \mathrm{M}^{-1} \mathrm{~s}^{-1}$ ) outside cells but not within cells. The hydroxyl radical adduct arose thus from the reduction of DEPMPO$\mathrm{OOH}$ in cells and not from trapping of hydroxyl radical resulting from superoxide disproportionation (Figure 1)[23].

Oxygen supply is critical in spin trapping experiments[31]. Previously we observed, using PMA-stimulated RAW macrophage suspensions[24], that spin trapping was enhanced in gaspermeable PTFE tubing, compared to glass microcapillary pipettes. Here, using adherent cells, different levels of detection were obtained depending on the way the coverslip glasses were mounted onto the quartz slide. When the cell-layer faces outwards, molecular oxygen is constantly replenished through equilibration with air, whereas it is expected to be rapidly consumed when the macrophages are sandwiched between glass and quartz walls or enclosed in ESR flat cells. The increase in ESR signal when the cell-layer faced outwards could be linked to a better diffusion of oxygen to the cell layer in two ways. First, increase in formation of DEPMPO-OOH (and subsequently of DEPMPO-OH) could be the result of an increased superoxide production by NOX2 when availability of oxygen, the substrate of the enzyme, increases. Second, reductases are known to be activated under anaerobic conditions and could reduce the spin adducts to diamagnetic compounds faster upon oxygen deprivation, a process that has been studied with sterically hindered nitroxides[42,43].

Our protocol using cells attached to microscope coverslip glasses has many advantages over previous methods. ESR measurement is performed on adherent cells and preserves cellular integrity. Cell harvesting generally involves enzymatic digestion, such as trypsinization, and mechanical detachment methods such as scraping. However these harvesting methods are known to cause damage to the cells. Enzymatic treatment damages cell membranes by partial hydrolysis of various membrane-expressed proteins and thus impairs cell function[44-48]. Scraping inflicts physical damage on cells and reduces their viability[49,50]. Scraping also 
alters the metabolic rates of cells (measured as nitroxide reduction kinetics)[51]. Moreover it was shown in several studies that cell detachment induces an increase in cellular ROS[5254]. The procedure described in this work is thus considerably less liable to artifacts linked with non-physiological production of ROS and to misinterpretation of spin adduct accumulation in cells with impaired metabolism as implying higher ROS production. Moreover, commercial disposable coverslip glasses are easy to handle and enable studies on large numbers of samples and controls over a short period of time, which is not the case when the expensive and fragile ESR flat-cells are used. In addition, superoxide detection is performed with only 500000 cells, which is almost one-tenth as many cells as were used for our previous study using gas-permeable PTFE tubing[24].

On the whole, the relative amounts of each adduct obtained on adherent cells with different spin traps correlate those previously obtained on cell suspensions with larger cell numbers (1$5 \times 10^{6}$ cells/100 $\mu \mathrm{L}$ )[24], suggesting that like for polymorphonuclear leucocytes PMAinduced superoxide release by macrophages was independent of cell adhesion[29]. DIPPMPO, like DEPMPO, is characterized by a higher detection of the hydroxyl adduct as a product of reduction of the superoxide adduct inside cell, since these spin traps are known to enter cells[22,25]. Mito-DIPPMPO and CD-DIPPMPO, which are known not to form ESRdetectable adducts from low fluxes of hydroxyl radical[23], appear as more specific of superoxide. SOD-controls are then largely unnecessary with these spin traps to discriminate between superoxide or hydroxyl radical as the origin of the adduct formation. The extracellular localization of CD-DIPPMPO explains why the adducts are protected from degradation by intracellular components, whereas partial conversion of the superoxide to the hydroxyl adduct is observed with Mito-DIPPMPO, which was designed to enter the cell and target the mitochondria[34,35].

\section{Conclusion}

In conclusion, we confirmed that spin trapping with CD-DIPPMPO coupled to ESR detection enable specific detection of superoxide produced by PMA-stimulated macrophages, as previously observed with cell suspensions[24], but here the detection was performed on adherent cells without detachment from microscope coverslip glasses. The sample preparation proposed in this work is straightforward, requires small numbers of adherent cells, and can be used when stress involved in trypsinization or mechanical detachment has to be avoided. In addition, we expect the oxygen supply to be constant in our system, as opposed to closed ESR flat cells that promote hypoxia. ESR detection performed on undetached cells using this setup paves the way for a large number of applications. For example, it would enable convenient medium-throughput screening of antioxidants and ROSmodulating agents in various cell lines. Alternatively, it could be used to screen the stability of ESR imaging contrast agents, such as aminoxyl or triarylmethyl radicals[55], in the presence of cells, prior to in vivo studies.

\section{Acknowledgments}

The authors wish to thank Dr. J.-C. Drapier (CNRS UPR 2301, Gif-sur-Yvette, France) for the generous gift of RAW 264.7 macrophages. They are also deeply grateful to Dr. A. Rockenbauer (Institute of Molecular Pharmacology, Research Centre for Natural Sciences, Budapest, Hungary) for the use of his simulation program and for his precious advice 
This is an Accepted Manuscript of an article published by Taylor \& Francis in Free Radical Research on 5 June 2015, available online: http://www.tandfonline.com/0.3109/10715762.2015.1045504

regarding the simulation of the ESR spectra; to Dr. J.-L. Boucher for stimulating discussions during the course of this work and for his critical reading of the manuscript; and to Drs. Y.-M. Frapart and D. Mansuy for their scientific guidance at the beginning of this work.

\title{
Declaration of interest
}

The authors are indebted to CNRS and the Agence Nationale de la Recherche (ANR-09BLAN-0193-02, SPIN BioRad) for their financial support.

\begin{abstract}
Abbreviations
CD-DIPPMPO, 6-monodeoxy-6-mono-4-[(5-diisopropoxyphosphoryl-5-methyl-1-pyrroline$N$-oxide)-ethylenecarbamoyl-(2,3-di- $O$-methyl) hexakis (2,3,6-tri- $O$-methyl)]- $\beta$-cyclodextrin; DEPMPO, 5-diethoxyphosphoryl-5-methyl-1-pyrroline $\mathrm{N}$-oxide; $\quad$ DIPPMPO, 5diisopropoxyphosphoryl-5-methyl-1-pyrroline $\mathrm{N}$-oxide; DMPO, 5,5-dimethyl-1-pyrroline $\mathrm{N}$ oxide; DTPA, diethylene triamine pentaacetic acid; ESR, electron spin resonance (equivalent to EPR, electron paramagnetic resonance); Mito-DIPPMPO, (4R*, $\left.5 R^{*}\right)-5$ (diisopropyloxyphosphoryl)-5-methyl-4-[(\{[2-

(triphenylphosphonio)ethyl]carbamoyl \}oxy)methyl]pyrroline $\mathrm{N}$-oxide bromide; PEG, polyethylene glycol; PMA, phorbol 12-myristate 13-acetate; ROS, reactive oxygen species; SOD, superoxide dismutase.
\end{abstract}

\section{References}

[1] Bartosz G. Reactive oxygen species: destroyers or messengers? Biochem Pharmacol 2009;77:1303-1315.

[2] Janzen E. Spin Trapping. Acc Chem Res 1971;4:31-40.

[3] Green MR, Hill HA, Okolow-Zubkowska MJ, Segal AW. The production of hydroxyl and superoxide radicals by stimulated human neutrophils - measurements by EPR spectroscopy. FEBS Lett 1979;100:23-26.

[4] Rosen H, Klebanoff SJ. Hydroxyl radical generation by polymorphonuclear leukocytes measured by electron spin resonance spectroscopy. J Clin Invest 1979;64:1725-1729.

[5] Hume DA, Gordon S, Thornalley PJ, Bannister JV. The production of oxygen-centered radicals by bacillus-Calmette-Guerin-activated macrophages. An electron paramagnetic resonance study of the response to phorbol myristate acetate. Biochim Biophys Acta $1983 ; 763: 245-250$.

[6] Rosen GM, Freeman BA. Detection of superoxide generated by endothelial cells. Proc Natl Acad Sci 1984;81:7269-7273.

[7] Bannister JV, Bannister WH. Production of oxygen-centered radicals by neutrophils and macrophages as studied by electron spin resonance (ESR). Environ Health Perspect 1985;64:37-43.

[8] Britigan B, Rosen G, Chai Y, Cohen M. Do human neutrophils make hydroxyl radical Determination of free radicals generated by human neutrophils activated with a soluble or particulate stimulus using electron paramagnetic resonance spectrometry. J Biol 
Chem 1986;261:4426-4431.

[9] Britigan BE, Rosen GM, Thompson BY, Chai Y, Cohen MS. Stimulated human neutrophils limit iron-catalyzed hydroxyl radical formation as detected by spin-trapping techniques. J Biol Chem 1986;261:17026-17032.

[10] Hassett DJ, Britigan BE, Svendsen T, Rosen GM, Cohen MS. Bacteria form intracellular free radicals in response to paraquat and streptonigrin. Demonstration of the potency of hydroxyl radical. J Biol Chem 1987;262:13404-13408.

[11] Pou S, Cohen MS, Britigan BE, Rosen GM. Spin-trapping and human neutrophils. Limits of detection of hydroxyl radical. J Biol Chem 1989;264:12299-12302.

[12] Ramos CL, Pou S, Britigan BE, Cohen MS, Rosen GM. Spin trapping evidence for myeloperoxidase-dependent hydroxyl radical formation by human neutrophils and monocytes. J Biol Chem 1992;267:8307-8312.

[13] Bačić G, Spasojević I, Šećerov B, Mojović M. Spin-trapping of oxygen free radicals in chemical and biological systems: New traps, radicals and possibilities. Spectrochim Acta A Mol Biomol Spectrosc 2008;69:1354-1366.

[14] Finkelstein E, Rosen GM, Rauckman EJ. Production of hydroxyl radical by decomposition of superoxide spin-trapped adducts. Mol Pharmacol 1982;21:262-265.

[15] Locigno EJ, Zweier JL, Villamena FA. Nitric oxide release from the unimolecular decomposition of the superoxide radical anion adduct of cyclic nitrones in aqueous medium. Org Biomol Chem 2005;3:3220-3227.

[16] Kim MJ, Kim DW, Park JH, Kim SJ, Lee CH, Yong JI, Ryu EJ, Cho SB, Yeo HJ, Hyeon J, Cho S-W, Kim D-S, Son O, Park J, Han KH, Cho YS, Eum WS, Choi SY. PEP-1SIRT2 inhibits inflammatory response and oxidative stress-induced cell death via expression of antioxidant enzymes in murine macrophages. Free Radic Biol Med 2013;63:432-445.

[17] Ouari O, Hardy M, Karoui H, Tordo P. Recent developments and applications of the coupled EPR/Spin trapping technique (EPR/ST). In: RSC Publishing. Cambridge: Gilbert, B. C.; Murphy, D. M.; Chechik, V., eds.; 2011. p. 1-40.

[18] Frejaville C, Karoui H, Tuccio B, Lemoigne F, Culcasi M, Pietri S, Lauricella R, Tordo P. 5-Diethoxyphosphoryl-5-methyl-1-pyrroline N-oxide (DEPMPO) - a new phosphorylated nitrone for the efficient in-vitro and in-vivo spin-trapping of oxygencentered radicals. J Chem Soc-Chem Commun 1994;15:1793-1794.

[19] Liu KJ, Miyake M, Panz T, Swartz H. Evaluation of DEPMPO as a spin trapping agent in biological systems. Free Radic Biol Med 1999;26:714-721.

[20] Timmins GS, Liu KJ, Bechara EJ, Kotake Y, Swartz HM. Trapping of free radicals with direct in vivo EPR detection: a comparison of 5,5-dimethyl-1-pyrroline-N-oxide and 5diethoxyphosphoryl-5-methyl-1-pyrroline-N-oxide as spin traps for $\mathrm{HO}^{\circ}$ and $\mathrm{SO}_{4}{ }^{\circ}$. Free 
Radic Biol Med 1999;27:329-333.

[21] Khan N, Wilmot CM, Rosen GM, Demidenko E, Sun J, Joseph J, O'Hara J, Kalyanaraman B, Swartz HM. Spin traps: in vitro toxicity and stability of radical adducts. Free Radic Biol Med 2003;34:1473-1481.

[22] Chalier F, Tordo P. 5-Diisopropoxyphosphoryl-5-methyl-1-pyrroline N-oxide, DIPPMPO, a crystalline analog of the nitrone DEPMPO: synthesis and spin trapping properties. J Chem Soc-Perkin Trans 2 2002;12:2110-2117.

[23] Bézière N, Hardy M, Poulhès F, Karoui H, Tordo P, Ouari O, Frapart Y-M, Rockenbauer A, Boucher J-L, Mansuy D, Peyrot F. Metabolic stability of superoxide adducts derived from newly developed cyclic nitrone spin traps. Free Radic Biol Med 2014;67:150-158.

[24] Abbas K, Hardy M, Poulhès F, Karoui H, Tordo P, Ouari O, Peyrot F. Detection of superoxide production in stimulated and unstimulated living cells using new cyclic nitrone spin traps. Free Radic Biol Med 2014;71:281-290.

[25] Anzai K, Aikawa T, Furukawa Y, Matsushima Y, Urano S, Ozawa T. ESR measurement of rapid penetration of DMPO and DEPMPO spin traps through lipid bilayer membranes. Arch Biochem Biophys 2003;415:251-256.

[26] Ross MF, Kelso GF, Blaikie FH, James AM, Cochemé HM, Filipovska A, Da Ros T, Hurd TR, Smith R a. J, Murphy MP. Lipophilic triphenylphosphonium cations as tools in mitochondrial bioenergetics and free radical biology. Biochem Mosc 2005;70:222230.

[27] Culcasi M, Rockenbauer A, Mercier A, Clément J-L, Pietri S. The line asymmetry of electron spin resonance spectra as a tool to determine the cis:trans ratio for spin-trapping adducts of chiral pyrrolines N-oxides: the mechanism of formation of hydroxyl radical adducts of EMPO, DEPMPO, and DIPPMPO in the ischemic-reperfused rat liver. Free Radic Biol Med 2006;40:1524-1538.

[28] Hardy M, Bardelang D, Karoui H, Rockenbauer A, Finet J-P, Jicsinszky L, Rosas R, Ouari $\mathrm{O}$, Tordo $\mathrm{P}$. Improving the trapping of superoxide radical with a betacyclodextrin-5-diethoxyphosphoryl-5-methyl-1-pyrroline-N-oxide conjugate. Chem- Eur J 2009;15:11114-11118.

(DEPMPO)

[29] Tanigawa T, Kotake Y, Reinke LA. Spin trapping of superoxide from glass adherent polymorphonuclear leukocytes induced by $\mathrm{N}$-formylmethionyl-leucyl-phenylalanine. Free Radic Res Commun 1993;19:101-110.

[30] Nakagawa H, Moritake T, Tsuboi K, Ikota N, Ozawa T. Induction of superoxide in glioma cell line U87 stimulated with lipopolysaccharide and interferon-gamma: ESR using a new flow-type quartz cell. FEBS Lett 2000;471:187-190.

[31] Kotake Y, Reinke LA, Tanigawa T, Koshida H. Determination of the rate of superoxide generation from biological systems by spin trapping: use of rapid oxygen depletion to measure the decay rate of spin adducts. Free Radic Biol Med 1994;17:215-223. 
[32] Britigan BE, Roeder TL, Shasby DM. Insight into the nature and site of oxygencentered free radical generation by endothelial cell monolayers using a novel spin trapping technique. Blood 1992;79:699-707.

[33] Danhier P, Copetti T, De Preter G, Leveque P, Feron O, Jordan BF, Sonveaux P, Gallez B. Influence of cell detachment on the respiration rate of tumor and endothelial cells. PloS One 2013;8:e53324.

[34] Hardy M, Chalier F, Ouari O, Finet J-P, Rockenbauer A, Kalyanaraman B, Tordo P. Mito-DEPMPO synthesized from a novel $\mathrm{NH}_{2}$-reactive DEPMPO spin trap: a new and improved trap for the detection of superoxide. Chem Commun 2007;1083-1085.

[35] Hardy M, Rockenbauer A, Vasquez-Vivar J, Felix C, Lopez M, Srinivasan S, Avadhani N, Tordo P, Kalyanaraman B. Detection, characterization, and decay kinetics of ROS and thiyl adducts of Mito-DEPMPO spin trap. Chem Res Toxicol 2007;20:1053-1060.

[36] Rockenbauer A, Korecz L. Automatic computer simulations of ESR spectra. Appl Magn Reson 1996;10:29-43.

[37] Beckman JS, Minor RL, White CW, Repine JE, Rosen GM, Freeman BA. Superoxide dismutase and catalase conjugated to polyethylene glycol increases endothelial enzyme activity and oxidant resistance. J Biol Chem 1988;263:6884-6892.

[38] Forman HJ, Torres M. Reactive oxygen species and cell signaling: respiratory burst in macrophage signaling. Am J Respir Crit Care Med 2002;166:S4-8.

[39] Reinke LA, Moore DR, McCay PB. Degradation of DMPO adducts from hydroxyl and 1-hydroxyethyl radicals by rat liver microsomes. Free Radic Res 1996;25:467-474.

[40] Khramtsov V, Berliner LJ, Clanton TL. NMR spin trapping: Detection of free radical reactions using a phosphorus-containing nitrone spin trap. Magn Reson Med 1999;42:228-234.

[41] Bézière N, Frapart Y, Rockenbauer A, Boucher J-L, Mansuy D, Peyrot F. Metabolic stability of superoxide and hydroxyl radical adducts of a cyclic nitrone toward rat liver microsomes and cytosol: A stopped-flow ESR spectroscopy study. Free Radic Biol Med 2010;49:437-446.

[42] Swartz HM. Use of nitroxides to measure redox metabolism in cells and tissues. J Chem Soc Faraday Trans 1 Phys Chem Condens Phases 1987;83:191-202.

[43] Rosen GM, Rauckman EJ. Formation and reduction of a nitroxide radical by liver microsomes. Biochem Pharmacol 1977;26:675-678.

[44] Revel JP, Hoch P, Ho D. Adhesion of culture cells to their substratum. Exp Cell Res 1974;84:207-218.

[45] Wu Y, Wu J, Lee DY, Yee A, Cao L, Zhang Y, Kiani C, Yang BB. Versican protects cells from oxidative stress-induced apoptosis. Matrix Biol 2005;24:3-13. 
[46] Piercy KT, Donnell RL, Kirkpatrick SS, Mundy BL, Stevens SL, Freeman MB, Goldman MH. Effect of harvesting and sorting on $\beta-1$ integrin in canine microvascular cells. J Surg Res 2001;100:211-216.

[47] Mutin M, George F, Lesaule G, Sampol J. Reevaluation of trypsin-EDTA for endothelial cell detachment before flow cytometry analysis. Endothelium 1996;4:289-295.

[48] Hirai H, Umegaki R, Kino-oka M, Taya M. Characterization of cellular motions through direct observation of individual cells at early stage in anchorage-dependent culture. $\mathrm{J}$ Biosci Bioeng 2002;94:351-356.

[49] Heng BC, Liu H, Ge Z, Cao T. Mechanical dissociation of human embryonic stem cell colonies by manual scraping after collagenase treatment is much more detrimental to cellular viability than is trypsinization with gentle pipetting. Biotechnol Appl Biochem 2007;47:33-37.

[50] McNeil PL. A method for incorporating macromolecules into adherent cells. J Cell Biol 1984;98:1556-1564.

[51] Batista U, Garvas M, Nemec M, Schara M, Veranic P, Koklic T. Effects of different detachment procedures on viability, nitroxide reduction kinetics and plasma membrane heterogeneity of V-79 cells. Cell Biol Int 2010;34:663-668.

[52] Lee J-W, Kim J-H. Activation of the leukotriene B4 receptor 2-reactive oxygen species (BLT2-ROS) cascade following detachment confers anoikis resistance in prostate cancer cells. J Biol Chem 2013;288:30054-30063.

[53] Chanvorachote P, Chunhacha P. Caveolin-1 regulates endothelial adhesion of lung cancer cells via reactive oxygen species-dependent mechanism. PloS One 2013;8:e57466.

[54] Kerkweg U, Petrat F, Korth H-G, de Groot H. Disruption of skeletal myocytes initiates superoxide release: contribution of NADPH oxidase. Shock 2007;27:552-558.

[55] Bézière N, Decroos C, Mkhitaryan K, Kish E, Richard F, Bigot-Marchand S, Durand S, Cloppet F, Chauvet C, Corvol M-T, Rannou F, Xu-Li Y, Mansuy D, Peyrot F, Frapart YM. First combined in vivo X-ray tomography and high-resolution molecular electron paramagnetic resonance (EPR) imaging of the mouse knee joint taking into account the disappearance kinetics of the EPR probe. Mol Imaging 2012;11:220-228.

\section{Supplementary material available online}

Supplementary Figure 1 to be found online at http://informahealthcare.com/doi/abs/10.3109/10715762.2015.1045504 
This is an Accepted Manuscript of an article published by Taylor \& Francis in Free Radical Research on 5 June 2015, available online: http://www.tandfonline.com/0.3109/10715762.2015.1045504

\section{Tables}

Table 1: Parameters used for the simulation of the spectra in Figure 1.

\begin{tabular}{|c|c|c|c|c|c|}
\hline Spin adduct (\% in the simulation) & Conformer & $\mathbf{A p}_{\mathbf{P}}(\mathbf{m} \mathbf{T})$ & $A_{N}(\mathbf{m} \mathbf{T})$ & $\mathbf{A}_{\mathbf{H} \circledast}(\mathbf{m} \mathbf{T})$ & $\mathbf{A}_{\mathbf{H} \gamma}(\mathbf{m T})$ \\
\hline DEPMPO-OH (90\%) & $\begin{array}{l}\mathrm{T} 1(53 \%) \\
\mathrm{T} 2(47 \%) \\
-\end{array}$ & $\begin{array}{l}5.19 \\
4.85 \\
4.71\end{array}$ & $\begin{array}{l}1.31 \\
1.32 \\
1.40\end{array}$ & $\begin{array}{l}1.19 \\
1.01 \\
1.32\end{array}$ & $\begin{array}{l}0.08 \\
0.09 \\
-\end{array}$ \\
\hline $\begin{array}{l}\text { DIPPMPO-OOH trans (10\%) } \\
\text { DIPPMPO-OH }(90 \%)\end{array}$ & $\begin{array}{l}\mathrm{T} 1(48 \%) \\
\mathrm{T} 2(52 \%)\end{array}$ & $\begin{array}{l}5.17 \\
4.79 \\
4.68\end{array}$ & $\begin{array}{l}1.30 \\
1.32 \\
1.40\end{array}$ & $\begin{array}{l}1.20 \\
1.02 \\
1.33\end{array}$ & $\begin{array}{l}0.06 \\
0.09 \\
-\end{array}$ \\
\hline Mito-DIPPMPO-OH (20\%) & $\begin{array}{l}\mathrm{T} 1(52 \%) \\
\mathrm{T} 2 \text { (48\%) } \\
-\end{array}$ & $\begin{array}{l}5.33 \\
5.29 \\
5.29\end{array}$ & $\begin{array}{l}1.28 \\
1.29 \\
1.36\end{array}$ & $\begin{array}{l}1.48 \\
0.87 \\
1.05\end{array}$ & - \\
\hline CD-DIPPMPO-OOH trans (100\%) & $\begin{array}{l}\text { T1 (54\%) } \\
\text { T2 (46\%) }\end{array}$ & $\begin{array}{l}5.34 \\
5.26\end{array}$ & $\begin{array}{l}1.26 \\
1.30\end{array}$ & $\begin{array}{l}1.25 \\
1.12\end{array}$ & - \\
\hline
\end{tabular}




\section{Legends for figures}

Figure 1: Structure of the spin traps under study and general principles of spin adduct formation and decay.

Figure 2: Experimental procedure for superoxide detection on adherent cells. On the day prior to experiment, RAW macrophages in $500 \mu \mathrm{L}$ DMEM were placed on round microscope coverslip glasses inserted in a 24-well culture plate. When indicated, confluent cells on two coverslips (250 000 cells/coverslip) were stimulated with PMA $\left(5 \mu \mathrm{M}, 20 \mathrm{~min}, 37^{\circ} \mathrm{C}\right)$, then washed twice with PBS, and incubated for $20 \mathrm{~min}$ at $21^{\circ} \mathrm{C}$ with the desired spin trap (5-10 $\mathrm{mM})$ in $150 \mu \mathrm{L}$ PBS containing DTPA $(1 \mathrm{mM})$. Both coverslips were then mounted on a quartz slide using vacuum grease and introduced in the ESR cavity equipped with a flat quartz protection sleeve. Sequential ESR spectra were recorded for $10 \mathrm{~min}$ as indicated under Methods.

Figure 3: Comparison of ESR spectra obtained in the presence of PMA-stimulated RAW macrophages attached to two microscope coverslip glasses. Activation of the macrophages (250 000 cells/coverslip) was performed for 20 min with $5 \mu \mathrm{M}$ PMA at $37^{\circ} \mathrm{C}$ and followed by incubation with DEPMPO $(10 \mathrm{mM})$, DIPPMPO $(10 \mathrm{mM})$, Mito-DIPPMPO $(10 \mathrm{mM})$, or CD-DIPPMPO (5 mM) for $20 \mathrm{~min}$ in PBS (pH 7.1-7.4) containing $1 \mathrm{mM}$ DTPA at $21^{\circ} \mathrm{C}$. ESR settings are described under Methods. The experimental spectra (black lines) are the sum of ten scans and are representative of three independent experiments. Calculated signals using parameters from Table 1 are shown as grey lines. We observe on the lower-right panel that the linewidth of CD-DIPPMPO-OOH spectrum is larger than that of DEPMPO$\mathrm{OOH}$ and DEPMPO-OH adducts (upper-left panel) due to a higher molecular tumbling correlation time. As a consequence, the signal-to-noise ratio obtained with CD-DIPPMPO is not as high as with DEPMPO even if the amount of spin adducts is similar.

Figure 4: Concentration of superoxide and hydroxyl radical adducts of the studied spin traps obtained with PMA-stimulated RAW macrophages attached to two microscope coverslip glasses. Activation of the macrophages (250 000 cells/coverslip) was performed for 20 min with $5 \mu \mathrm{M}$ PMA at $37^{\circ} \mathrm{C}$ and followed by incubation with DEPMPO $(10 \mathrm{mM})$, DIPPMPO $(10 \mathrm{mM})$, Mito-DIPPMPO $(10 \mathrm{mM})$, or CD-DIPPMPO $(5 \mathrm{mM})$ for $20 \mathrm{~min}$ in PBS (pH 7.1-7.4) and $1 \mathrm{mM}$ DTPA at $21^{\circ} \mathrm{C}$. The concentration of each adduct expressed in arbitrary unit was derived from computer simulation of the ESR spectra by normalized lineshapes as described under Methods. The data are the average of three independent experiments and the error bars reflect the standard deviation. The hydroxyl adduct of CDDIPPMPO was under the limit of detection of our method. 
This is an Accepted Manuscript of an article published by Taylor \& Francis in Free Radical Research on 5 June 2015, available online: http://www.tandfonline.com/0.3109/10715762.2015.1045504

\section{Figures}

\section{Figure 1}<smiles>CC1(PO)CCC=[N+]1[O-]</smiles>

DEPMPO: $\quad \mathrm{R}=\mathrm{C}_{2} \mathrm{H}_{5}$ DIPPMPO: $\mathrm{R}=\mathrm{CH}\left(\mathrm{CH}_{3}\right)_{2}$<smiles>CCNC(=O)OCC1CC=[N+]([O-])C1(C)OC(C)C</smiles>

Mito-DIPPMPO: $\mathrm{R}^{\prime}=\mathrm{CH}_{2} \mathrm{CH}_{2} \mathrm{PPh}_{3}{ }^{+} \mathrm{Br}$ CD-DIPPMPO: $\quad R^{\prime}=$ methyl- $\beta$-cyclodextrin

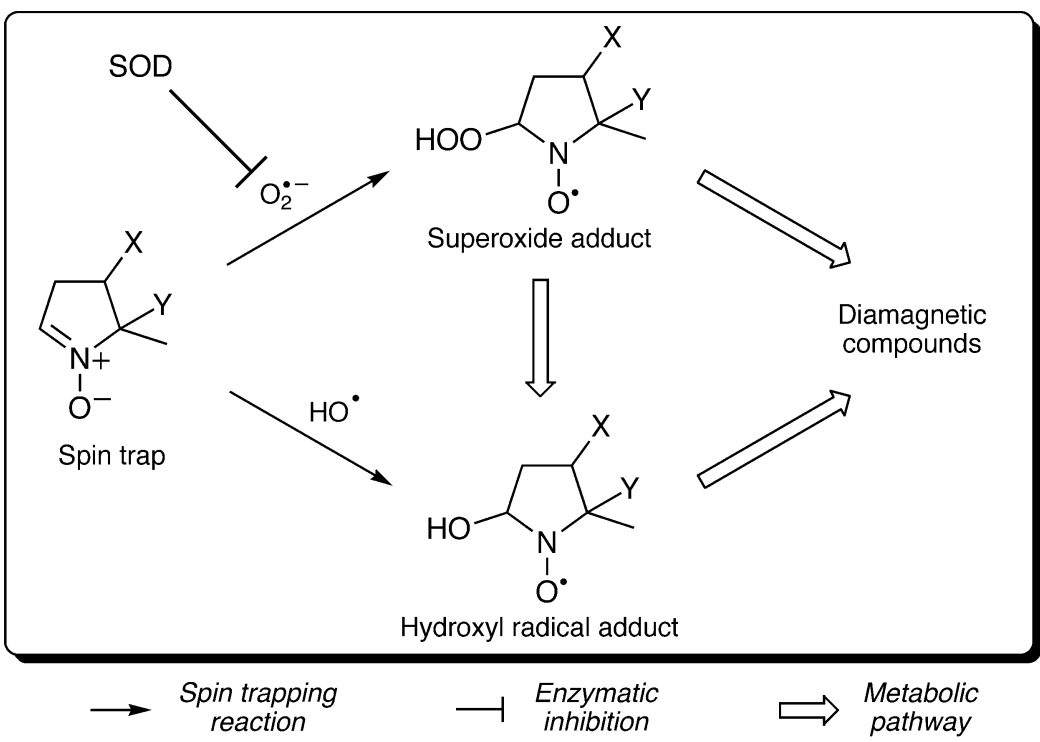


This is an Accepted Manuscript of an article published by Taylor \& Francis in Free Radical Research on 5 June 2015, available online: http://www.tandfonline.com/0.3109/10715762.2015.1045504

\section{Figure 2}
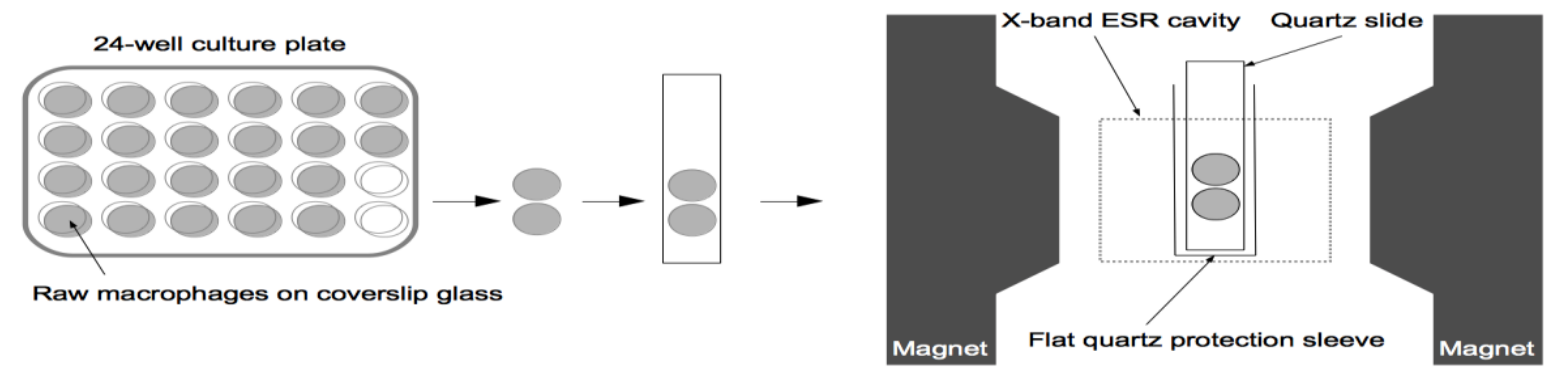
This is an Accepted Manuscript of an article published by Taylor \& Francis in Free Radical Research on 5 June 2015, available online: http://www.tandfonline.com/0.3109/10715762.2015.1045504

\section{Figure 3}

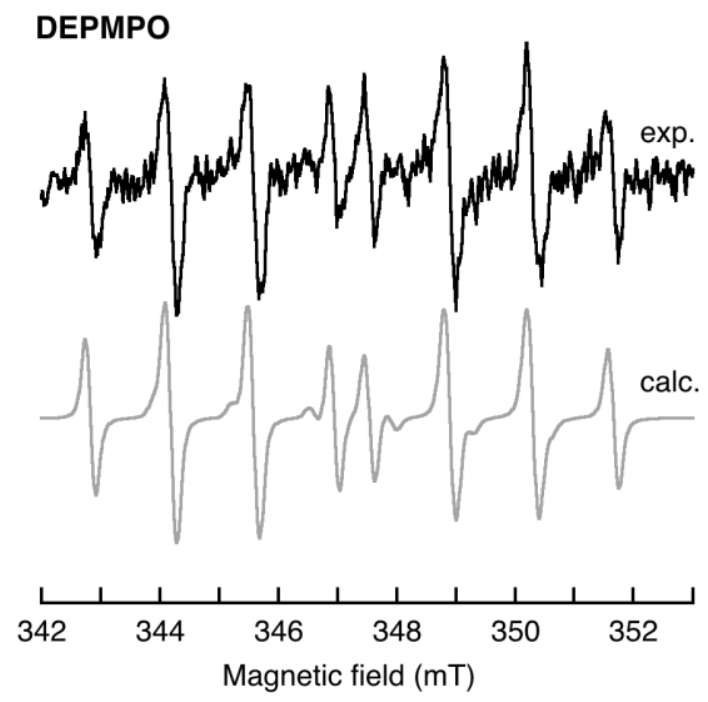

DIPPMPO

Mito-DIPPMPO

CD-DIPPMPO
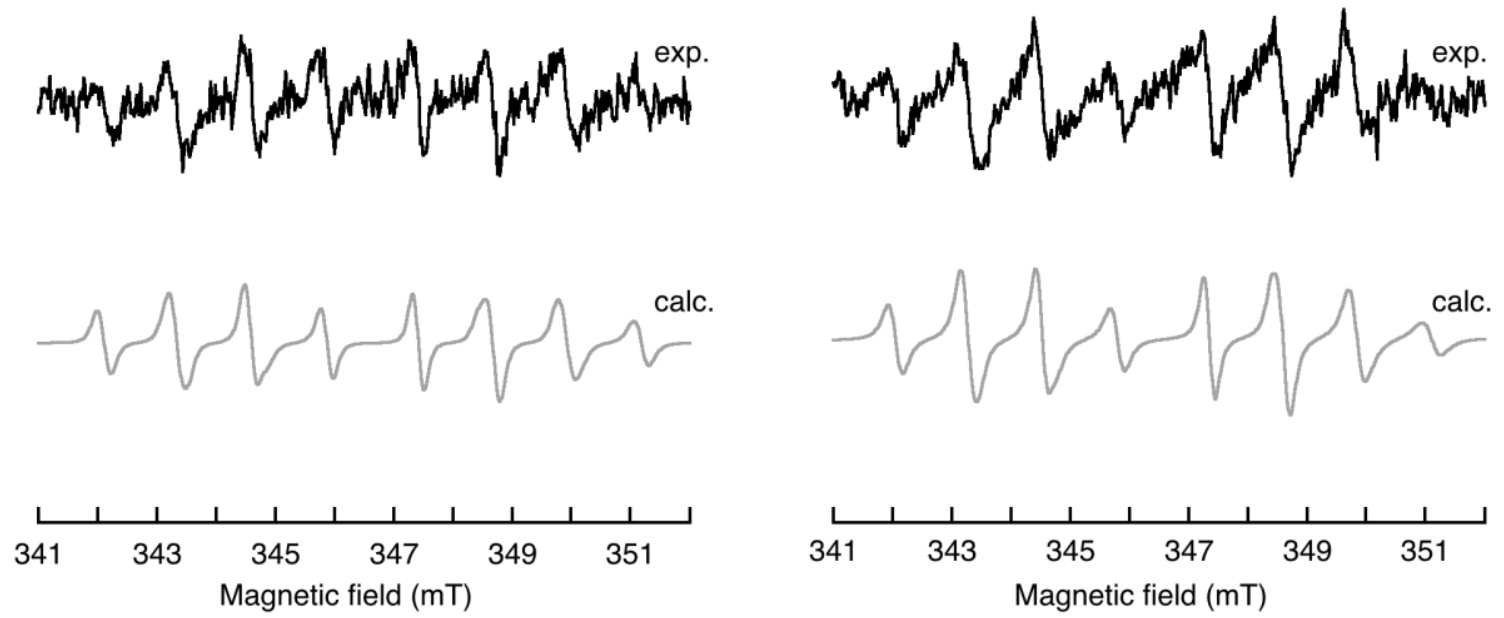
This is an Accepted Manuscript of an article published by Taylor \& Francis in Free Radical Research on 5 June 2015, available online: http://www.tandfonline.com/0.3109/10715762.2015.1045504

\section{Figure 4}

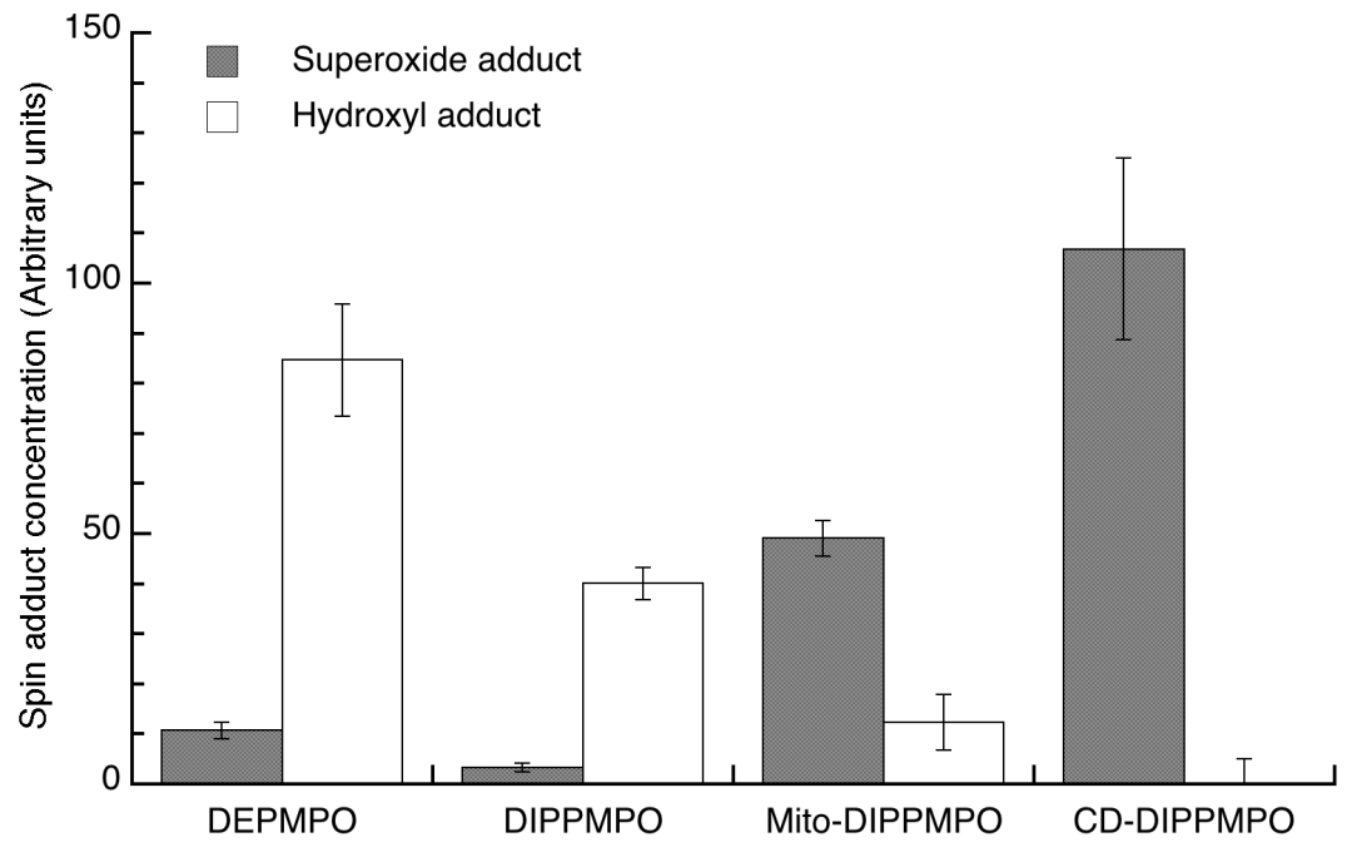

